\title{
The Effect of Multiple Texts on the Inquiry of Big Questions in the Affective Domain
}

\author{
Shu-Hua Tang \\ National Taiwan Normal University, Taiwan, R.O.C.
}

\begin{abstract}
The purpose of the present study was to explore how junior high students could benefit from reading multiple texts on the inquiry of big questions concerning adolescent developmental issues. Thirtyseven $8^{\text {th }}$ grade junior high students were recruited to participate in this project. Questionnaires were first adopted to investigate their types of interests on big questions, their reading attitude, and their preferences about outside readings. Then an action research followed to develop a literature-based program to promote their growth on big ideas. It is hoped that by depicting a clearer relation between multiple texts and the attainment of big ideas, this study would have implications for theories of reading comprehension using multiple texts, and for the future design and choice of feasible instructional materials in affective education.
\end{abstract}

\section{Introduction}

This study is a two-year (2012-2013) project, and this paper presents Year 1 tentative findings. The main purpose of this project was to explore the effect of multiple texts on adolescents' inquiry of big questions concerning developmental issues. Although the reading movements to encourage K-12 teachers implementing content area literacy is in full swing, outside reading is still not taken seriously by most K-12 Taiwan's teachers. In 2010-2011, the research team had attempted to infuse reading activities in History and found promising results. In 2012- 2013, we thus expanded the research scope in which multiple texts were used and topics were selected around "big questions."

Junior high school is a stressful stage for many students as they go through the process of adapting to new educational and social environments. They struggle with their identity and socialization issues. Particularly, they need to learn how to strategically solve developmental problems in order to successfully function in their daily lives. In essence, they need to be equipped with the abilities to ask and answer essential life questions, such as, what is fairness? Why should we respect differences? How to act responsibly? [1] Wiggins and McTighe (2005) contended that "big ideas...should be the focus of education for understanding. A big idea is a concept, theme, or issue that gives meaning and connecting to discrete facts and skills." (p.5) [2] Thus, the present study attempted to connect adolescent literature with students' life experiences.

In Taiwan, due to the rigorous entrance examinations for high schools, junior high students almost stop outside reading and become a group of people who reads least, borrows the least quantity of books, and has the least suitable books [3]. Apparently, different strategies to promote reading activities for junior high students are called for. We believe that engaging adolescents with texts and discussions about these issues while they are still in school is challenging but important and urgent. As aforementioned situation continues to exist in Taiwan, almost all teaching in junior high school is exam-driven, textbook based and lecture oriented. Therefore, how to infuse affective issues into reading with broader scope and deeper knowledge acquisition in mind is the main focus of this study.

\section{Literature Review}

The conception of reading-to-learn is well acknowledged in education nowadays. In particular, to read purposefully is crucial for secondary school students, since they have getting beyond the basic literacy skills [4]. Good books not only help adolescents make connections between the world and their personal experiences but also revise these young adults' notions about the world through literature.

Adopting Halliday's framework, Short contended that in a literature-rich curriculum, the balance is needed among three types of engagements: learn language, learn about language, and learn through language [5]. Learning language means children learn to read by reading and by being surrounded by other readers (e.g., independent reading, read aloud, book talks, etc.). In many primary classrooms, for example, students may need more of this aspect of intensive engagements.

Likewise, learning about language also emphasizes more on language in general, and reading strategies in particular. When students lack reading proficiency, teachers will explicitly teach them to examine the nature and function of language and literature. By reflect on their reading processes, students become proficient readers.

In contrast, learning through language is a way of learning about the world and oneself. Short suggested that through dialogue and response to literature and 
using books to investigate their questions, children become literate. Short pointed out that although upper grade students need this aspect of engagement but in fact they often spend most of their time reading content materials and rarely have time to simply enjoy a good book. Therefore, Short contended that students need to read widely and continue developing fluency and flexibility as readers.

Agreeing with Short's argument, the present study also considers it is our responsibility to involve students with high quality books. However, it is important to note that wide reading does not necessarily mean more learning unless intertextuality is present. [6]

According to Hartman and Allison, there are a number of ways to think about the relationships among texts: complementary, conflicting, controlling, synoptic, and dialogic [6]. Yet, regardless of how texts are arranged, they suggested that the primary concern should always be with how these texts can promote students inquiry learning. Therefore, how to design activities to enhance students' efforts in exploring and relating multiple texts is a crucial issue.

Research suggests that readers who are able to transform and integrate information from multiple texts may gain deeper understanding of the subject matter [9]. Kintsch's Construction-Integration Model (CI Model) also explains how readers respond to the text at hand (local structure or microstructure), and connect the current text with other situations (global structure or macrostructure) [10]. Therefore, the reader would integrate the information provided by the current text with prior knowledge, reorganize and restructure prior knowledge in terms of the reader's understanding of the knowledge domain as a whole rather than the particular text just read.

In addition, not only could students construct their understanding through reading texts independently, they could also form the concept cooperatively. Guthrie and McCann positioned that when students are expected to challenge their peers and defend their own explanations, they acquire a more flexible conceptual understanding than they do in isolated learning contexts [11].

Based on the aforementioned research framework, this project attempts to use trade books and adolescent literature as main sources of outside readings to help students approach big questions.

\section{Research Rationales}

Thirty-seven $8^{\text {th }}$ grade junior high students were recruited to participate in Year 1 study. It was consisted of two phases: (1) to investigate students' type of big questions, and their reading attitude as well as reading preferences about outside readings, questionnaires were conducted in the first phase of the study; (2) to develop a feasible literature-based curriculum to promote their growth on big ideas, an action research followed. The rationale for adopting such method was twofold. First, the method was more flexible in reflecting on what is occurring in the classroom, which suited the researcher better for selecting appropriate literature. Second, certain topics seemed to work better when the researcher and the class teacher collaboratively led the discussion, and action research allowed the possibilities. This action research had lasted for one semester (2012/9 2013/1) and met on the weekly basis.

To select adolescent literature that could serve the purpose of this study, the research first went through the suggested booklists from Taipei Public Library, and three awards for outstanding adolescent literacy were targeted. They were: "the Newbery Medal", "A Good Book You Read" and "GIO Primary and Secondary School Students Excellent Extracurricular Reading".

After screening books thoroughly, we finally selected 15 books. They are listed in Table 1.

Table 1. Books selected by this study

\begin{tabular}{|c|c|}
\hline Book Title & Award \\
\hline Lily's Crossing & $\begin{array}{l}\text { A } 1998 \\
\text { Newbery Honor }\end{array}$ \\
\hline Sarah,Plain and Tall & $\begin{array}{l}\text { The } 1986 \\
\text { Newbery Medal }\end{array}$ \\
\hline The high power of Lucky & $\begin{array}{l}\text { The } 2007 \\
\text { Newbery Medal }\end{array}$ \\
\hline Crazy Lady & $\begin{array}{l}\text { A } 1994 \\
\text { Newbery Honor }\end{array}$ \\
\hline Straberry Girl & $\begin{array}{l}\text { The } 1946 \\
\text { Newbery Medal }\end{array}$ \\
\hline All Alone In The Universe & $\begin{array}{l}\text { GIO Primary } \\
\text { and Secondary } \\
\text { School Students } \\
\text { Excellent } \\
\text { Extracurricular } \\
\text { Reading }\end{array}$ \\
\hline $\begin{array}{l}\text { The Penderwicks: A Summer } \\
\text { Tale of Four Sisters, Two } \\
\text { Rabbits, and a Very Interesting } \\
\text { Boy }\end{array}$ & $\begin{array}{l}\text { GIO Primary } \\
\text { and Secondary } \\
\text { School Students } \\
\text { Excellent } \\
\text { Extracurricular } \\
\text { Reading }\end{array}$ \\
\hline Rabbit Hill & $\begin{array}{l}\text { The } 1945 \\
\text { Newbery Medal }\end{array}$ \\
\hline Hope Was There & $\begin{array}{l}\text { GIO Primary } \\
\text { and Secondary } \\
\text { School Students } \\
\text { Excellent } \\
\text { Extracurricular } \\
\text { Reading }\end{array}$ \\
\hline The Hundred Dresses & $\begin{array}{l}\text { A } 1945 \\
\text { Newbery Honor }\end{array}$ \\
\hline The Great Gilly Hopkins & $\begin{array}{l}\text { A } 1979 \\
\text { Newbery Honor }\end{array}$ \\
\hline Bud, Not Buddy & $\begin{array}{l}\text { the } 2000 \\
\text { Newbery Medal }\end{array}$ \\
\hline Because of Winn-Dixie & $\begin{array}{l}\text { A } 2001 \\
\text { Newbery Honor }\end{array}$ \\
\hline Missing May & the 1993 \\
\hline
\end{tabular}




\begin{tabular}{|l|l|}
\hline & Newbery Medal \\
\hline Kensuke's kingdom & The 50th "A \\
& $\begin{array}{l}\text { Good Book You } \\
\text { Read" }\end{array}$ \\
\hline
\end{tabular}

There was no lecture involved. Students were grouped by 3-5 people based on their interest. Every week students would meet and choose books to read. They first read silently, and then work cooperatively with group members. To tap into students' prior knowledge and monitor their reading process, students were asked to fill in the KWLA worksheet before and during reading [13]. To compare and contrast each group member's opinion, students then used the I-Chart as the reflection guide [13]. At the end of the study, we collected students' concept map on big ideas to see how they organized information learned from multiple texts and group discussion.

\section{Analysis of Findings}

\subsection{Students' interest on big questions}

To understand students' interest on big questions, we designed a 6-point Likert-typed survey ("1" means "the least important", and " 6 " means "the most important"), in which 28 questions adopted from Burke were chosen and translated in Chinese [15]. The results showed that the top 5 issues that students rated most important were all about interpersonal issues: (1) "How to make sure my friends like me? $(\mathrm{M}=5.32, \mathrm{SD}=0.97),(2)$ "How to get along with my friends?" $(\mathrm{M}=5.22, \mathrm{SD}=1.23),(3)$ "How do I look in others' eyes?" $(\mathrm{M}=5.1, \mathrm{SD}=1.3)$, (4) "How do my friends trust me?" (M=4.97, $\mathrm{SD}=1.26)$, and (5) "How to win over friendships?" $(\mathrm{M}=4.95, \mathrm{SD}=1.29)$.

As we can see, most students have great interests on big questions involving interpersonal issues. However, it's quite ironic that these questions are seldom discussed in school. This finding is in line with Taiwan's education, in which reading and learning matter only for exams.

\subsection{Students' reading attitude and preferences}

In order to find out students' attitude toward reading and their preferences of outside reading, we designed a 6-point Likert-typed survey ("1" means "the least important", and " 6 " means "the most important"), in which 56 questions concerning their general attitude toward reading were assessed. Questions were partly chosen and revised from Richardson, Morgan, and Fleener [14]. In addition, we provided them a few open-ended questions so they can fill in the types of books they mostly read in the leisure time. \ulcorner\lrcorner
It was shown that junior high students seemed to hold quite positive attitude toward reading. The items rated higher than 5-point (which means "Agree" or "Totally Agree") were: (1) "Reading helps me form values and concepts about life" ( $\mathrm{M}=5.16, \mathrm{SD}=.87)$, (2) "I like to learn new stuff from reading" $(\mathrm{M}=5.11$, $\mathrm{SD}=1.02)$, and (3) "I will still keep reading even when I am no longer a student" (M=5.05, $\mathrm{SD}=1.37)$.

On the other hand, when asked about what types of books they like to read in their leisure time, the findings were quite worrisome. Romance and Cartoons were the most read books by the students. In addition, the particular genre called "light novels" was also endorsed by many students. According to Wikipedia, this writing style is short, light, and fully illustrated. The primary goal is to please the new generation [16].

Although it is hard to conclude that students' taste was bad, it is fair enough to say that these readings can hardly touch the serious issues concerning big questions. It is such a pity since these students don't have much free time to read after spending so much time in studying. However, when they do find time to read, they do not read serious (good?) books. This phenomenon deserves further exploration. In particular, we think it is necessary to take action to expand adolescents' reading taste. The following study was steered by this concern.

\subsection{The effect of the literature-based program}

To explore the possibility that providing students with awarded adolescent literature and the peer discussion activity might ease the problem mentioned above, an action research was then conducted in the second phase. It was hoped that we could help these young adults become strategic problem solvers and lifelong learners through engaging them to read purposefully.

To start with, during the first week of the study we surveyed students' interest of big questions and then adopted the self-select strategy in which the awarded young adult literature (see Table 1) was put in the corners and students could pick the book they liked to read. There should be enough access for them to choose since each title was prepared with three to four copies.

However, out of our surprise, their decisions were quite unmindful. Most students reported that they made the choice purely just by previewing the book title or the drawing on the cover page. Only one or two did read the abstract or the preface before they chose. It seemed to us that teaching adolescents to mindfully select books and "not judge a book by its cover" sounded trivial but indeed is important.

After selecting the book, they read silently at their own pace. When they finished the book, they could freely initiate the conversation with group members. 
The survey to rate their perceptions about each reading activity was completed at the last week of the study. It was found that either the independent reading or the group conversations had its own merits. According to students' feedback, 20 students rated the reading material as "helpful" to understand the big questions, and 25 students rated the discussion activity "helpful". However, it was out of our surprise that some students appreciated even more about the group discussion. For example, 6 students changed their attitude from "not helpful" to "helpful" after discussing with peers. In addition, when asked about "what do you consider the most interesting activity this semester we have", 10 students wrote "discussion with peers". Therefore, both quality literature and meaningful dialogues with others all seemed to contribute in grasping the big ideas for students.

It is worthwhile to mention that reading with questions at hand was such a new experience that 11 students commented that "to think along while reading" was the most interesting activity. As de Bono coined the term "two-finger thinking", a lot of classrooms indeed foster this dependence inadvertently! This is why Richardson, Morgan, and Fleener strongly suggested that teachers should use reading as an effective tool to empower students to become autonomous learners [17]. The present study supported their argument and found that reading-tolearn was indeed a welcomed idea by adolescents.

The study also collected students' concept maps at the end of the program. By doing so, we were trying to make inferences about the quality of students' engaged reading. Although the scoring rubric for concept maps is still developing, we found that most students did engage in their reading seriously and tried to organize what they had read into a more consistent framework. For example, one of the students, Wen, read the fiction, The Great Gilly Hopkins. This is a book about a brilliant but brash girl who had lived with various foster homes and become an angry person who hated everybody. She finally realizes that her maternal mother doesn't really love her and who she really loved was the foster mother. But it had been too late.

The big question Wen trying to answer was: How to understand others? This is the concept map he drew (see Figure 1).

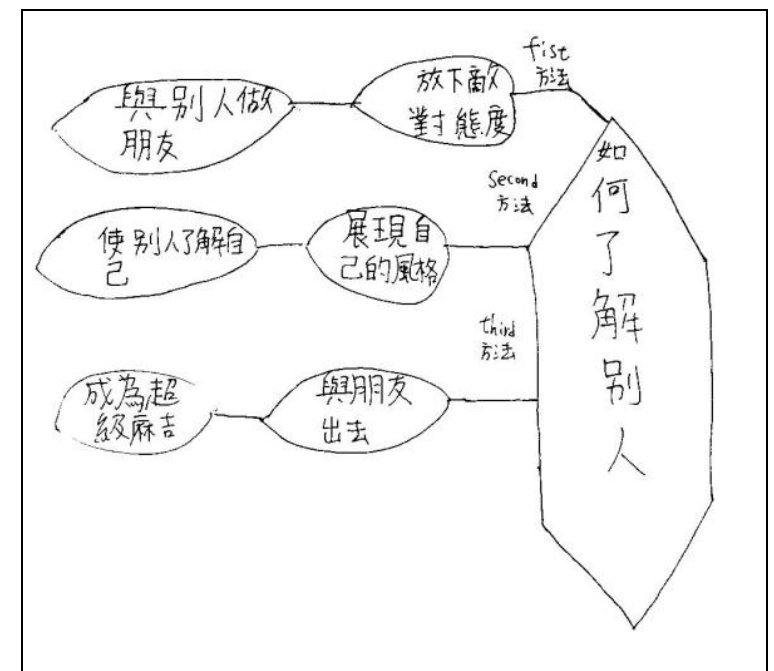

Figure 1. Wen's Concept Map

As shown in Figure 1, Wen summarized three strategies to understand others: (1) you need to first withdraw your hostility toward others so you could make friends with them, (2) you need to confidently present yourself so others could have a better chance to know you, and (3) you need to go out with them so you have a chance to observe who they really are and became good friends.

In fact, Wen himself was a rejected student by his classmates. He sometimes threw tantrum to others. I believed he chose this book for a good reason. I also believed this book had taught him quite a lot, since he needed to learn how to perceive others fairly and understand how others had perceived him.

Another student, Shey, read the book, The Hundred Dresses. This book centers on a poor and friendless Polish-American girl, Wanda. Wanda was teased by her classmates. One day, after her classmates laugh at her funny last name and the faded blue dress she wears to school every day, Wanda claims to own one hundred dresses, all lined up in her closet at her worn-down house. Unfortunately, this obvious lie causes her more trouble and finally makes Wanda's father decide to move away. The students who teased her feel remorse and want her to know that they are sorry. Marty, one of Wanda's classmates, wrote a sorry letter to confess that why she didn't help Wanda was because she was too afraid to stand up for her. She was also worried that she would be teased, too. The big question Shey interested in was: What are the talents I really have? 


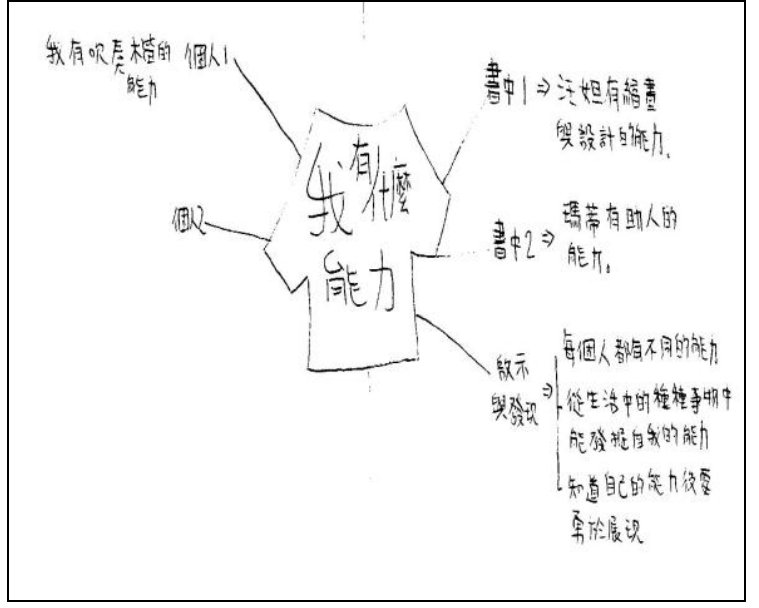

Figure 2. Shy’s Concept Map

By examining Shey's concept map (see Figure 2), we could tell that Shy was able to relate the fiction to his own experience. For example, on the left-hand side of the figure, he wrote down his talents in playing instruments. On the right-hand side, he concluded the book with 2 main points: (1) Wanda is talented in drawing and designing, and (2) Marty is indeed able to help. He also wrote the following reflection note:

Everyone has his/her own talent. We just have to find it out as hard as we could throughout our life. And when we did find our talents, we need to be brave, and fearlessly show it to others...

Shey was a quiet but talented student. Lacking of enough confidence, he also seldom presented himself in public (just like Wanda). I believed what he wrote in the reflection note was also a reminder to himself.

As Hynes and Hynes-Berry noted, when provided a reader with just the right book, it would trigger significant growth [18]. In this study, we saw the magic onto Wen and Shey. Therefore, taken the quantitative and qualitative data together, we had the tentative findings to believe that the extended and engaged reading could really help these young adults increase their depth of understanding in those developmental issues.

\section{Conclusions}

The present study attempted to explore junior high students' big questions, their reading attitude, and their preferences of outside reading. An action research was also conducted to verify the effects of adolescent literature on the growth of big ideas. By adopting different formats of worksheets (KWLA, IChart, etc.), we hoped to develop better instruments for students' inquiry. In general, the finding showed that students became more empathetic, more involved in the texts and issues, as they read more.
However, it is important to remember that we cannot assume students would select high quality books by themselves and could make connections among texts automatically. Therefore, teachers need to give students issues to think along while they are reading.

It is hoped that by depicting the relation between multiple texts and the forming of big ideas, the study would have implications for theories of reading comprehension for multiple texts, and for the design and choice of instructional materials in affective education. Overall, there is room for development for theories and educational implications of intertextuality, and further inquiry is needed.

\section{Acknowledgement}

This study is supported by Taiwan's NSC 1012420-H-003 -001 -MY2.

\section{Reference}

[1] Burke, J., (2010). What's the Big Idea? Question-driven Units to Motivate Reading, Writing, and Thinking. Portsmouth, NH: Heinemann.

[2] Wiggins, G., \& McTighe, J., (2005). Understanding by Design (2nd ed.). Alexandria, VA: Association for Supervision and Curriculum Development.

[3] Lin, 2007

[4] Biancarosa, C., \& Snow, C. E., (2006). Reading next$A$ vision for action and research in middle and high school literacy: A report to Carnegie Corporation of New York $\left(2^{\text {nd }}\right.$ ed.). Washington, DC: Alliance for Excellent Education.

[5] Short, K. G., (1999). The search for "balance" in a literature-rich curriculum. Theory into Practice, 38 (3), 130-137.

[6] Hartman, D. K., \& Allison, J., (1996). Promoting inquiry-oriented discussions using multiple texts. In L.B. Gambrell \& J. F. Almasi (Eds.), Lively Discussions! Fostering Engaged Reading (pp.106-133). Newark, DE: International Reading Association.

[7] Wiley, J. \& Voss, J. F., (1999). Constructing arguments from multiple sources: tasks that promote understanding and not just memory for text. Journal of Educational Psychology, 91(2), 301-311.

[8] Kintsch, W., (1988). The role of knowledge in discourse comprehension: a construction-integration model. Psychological Review, 95(2), 163-182.

[9] Guthrie, J. T., \& McCann, A. D., (1996). Idea circles: peer collaboration for conceptual learning. In L.B. Gambrell \& J.F. Almasi (Ed.), Lively Discussions! Fostering Engaged Reading (pp.87-105). Newark, DE: International Reading Association. 
[10] Richardson, J. S., Morgan, R. F., \& Fleener, C. E., (2012). Reading to Learn in the Content Areas (8th ed.). Belmont, CA: Wadsworth.

[11] Ogle, D., Klemp, R., \& McBride, B. (2007). Building Literacy in Social Studies: Strategies for Improving Comprehension and Critical Thinking. Alexandria, VA: ASCD.

[12] Burke, J., (2010). What's the Big Idea? Questiondriven Units to Motivate Reading, Writing, and Thinking. Portsmouth, NH: Heinemann.

[13] Richardson, J. S., Morgan, R. F., \& Fleener, C. E., (2012). Reading to Learn in the Content Areas (8th ed.). Belmont, CA: Wadsworth.

[14]Wikipedia, http://en.wikipedia.org/wiki/Light_novel (Access date: 22 March, 2013).

[15] Richardson, J. S., Morgan, R. F., \& Fleener, C. E., (2012). Reading to Learn in the Content Areas (8th ed.). Belmont, CA: Wadsworth.

[16] Hynes, A. M., \& Hynes-Berry, M., (1986). Bibliotherapy - the Interactive Process: A Handbook. Boulder, CO: Westview Press. 